OPEN ACCESS

Edited by: Gionata De Vico, University of Naples Federico II, Italy

Reviewed by: Alaa El-Din Hamid Sayed, Assiut University, Egypt

Rina Chakrabarti,

University of Delhi, India

*Correspondence:

Vincenzo Parrino

vincenzo.parrino@unime.it

tThese authors have contributed equally to this work and shared first authorship.

Specialty section: This article was submitted to Aquatic Physiology, a section of the journal Frontiers in Physiology

Received: 07 February 2018 Accepted: 03 May 2018 Published: 23 May 2018

Citation:

Acar Ü, Parrino V, Kesbiç OS, Lo Paro G, Saoca C, Abbate F, YIImaz $S$ and Fazio $F$ (2018) Effects of Different Levels of Pomegranate Seed Oil on Some Blood Parameters and Disease Resistance Against Yersinia ruckeri in Rainbow Trout. Front. Physiol. 9:596. doi: 10.3389/fphys.2018.00596

\section{Effects of Different Levels of Pomegranate Seed Oil on Some Blood Parameters and Disease Resistance Against Yersinia ruckeri in Rainbow Trout}

\author{
Ümit Acar ${ }^{1 t}$, Vincenzo Parrino ${ }^{2 * t}$, Osman Sabri Kesbiç ${ }^{3}$, Giuseppe Lo Paro ${ }^{2}$, \\ Concetta Saoca ${ }^{4}$, Francesco Abbate ${ }^{4}$, Sevdan YIImaz ${ }^{5}$ and Francesco Fazio ${ }^{4}$
}

\footnotetext{
'Bayramic Vocational School, Çanakkale Onsekiz Mart University, Çanakkale, Turkey, ${ }^{2}$ Department of Chemical, Biological, Pharmaceutical, and Environmental Sciences, University of Messina, Messina, Italy, ${ }^{3}$ Faculty of Veterinary, Kastamonu University, Kastamonu, Turkey, ${ }^{4}$ Department of Veterinary Sciences, University of Messina, Messina, Italy, ${ }^{5}$ Department of Aquaculture, Faculty of Marine Sciences and Technology, Çanakkale Onsekiz Mart University, Çanakkale, Turkey
}

This study is aimed to assess the effects of pomegranate seed oil (PSO) supplementation on growth performance, some hematological, biochemical and immunological parameters, and disease resistance against Yersinia ruckeri in cultured rainbow trout Oncorhynchus mykiss (Walbaum, 1792). 240 fish in total were randomly assigned into four triplicate groups (20 fish/per aquarium) corresponding to four dietary treatments: control ( $\mathrm{PSO}_{0}$; no addition of $\left.\mathrm{PSO}\right), 0.5 \%\left(\mathrm{PSO}_{5}\right), 1.00 \%\left(\mathrm{PSO}_{10}\right)$, and $2.00 \%\left(\mathrm{PSO}_{20}\right)$ of $\mathrm{PSO}$, respectively. After the 60 day-feeding trial, fish blood samples were collected and compared. Statistical analysis (one-way ANOVA) showed a significant $(P<0.05)$ effect of PSO on red blood cell count, hemoglobin concentration, mean corpuscular volume, mean corpuscular hemoglobin concentration, cholesterol, aspartate aminotransferase, alanine aminotransferase, and alkaline phosphatase parameters in $\mathrm{PSO}_{5}$ and $\mathrm{PSO}_{10}$ with regard to control. Moreover, a pronounced $(P<0.05)$ increased in weight gain, growth and feed conversion was found in fish fed with PSO supplemented diets. After the feeding trial, fish were challenged with Y. ruckeri and survival recorded for 20 days. Cumulative survival was $45.10 \%$ in fish fed with the control diet, whereas in fish fed with $\mathrm{PSO}_{5}, \mathrm{PSO}_{10}$, and $\mathrm{PSO}_{20}$ supplemented diets, survival was 58.82, 56.86, and 56.86\%, respectively. In conclusion, dietary administration of PSO induced a reduction in mortality of rainbow trout infected with Y. ruckeri, intercalary significant differences occurred on growth performance and some blood values among treated groups. These positive effects of PSO could be considered for new applications in aquaculture.

Keywords: herbal feed additives, growth performance, Oncorhynchus mykiss, Punica granatum, sustainable aquaculture 


\section{INTRODUCTION}

In aquaculture diseases such as bacterial and viral infections are controlled using antibiotics and other chemotherapeutics that also promote the growth performance (Sasmal et al., 2005), and therefore, ensure the animal welfare, but some of these substances have deleterious effect on animals, fish, and humans. Some natural plant origin products like vegetables, herbs, spices, edible plants, and their extracts are not explained as traditional feed additives for animal nutrition. This plant derivates that act as growth promoters, immunostimulants or antimicrobial agents, represents viable and alternative to the use of antibiotics and other chemotherapeutics which are not harmful for environment and which have fewer side effect then chemical drugs (Galindo-Villegas and Hosokawa, 2004).

The effect of herbal products on different species of fish was studied in several previous researches (Alishahi et al., 2011; Tangestani et al., 2011; Asadi et al., 2012; Haghighi and Sharif Rohani, 2013).

Johnson and Banerji (2007) showed that herbal extract as an additive promotes hematological and biochemical performance, enhances the fish growth, and also protects from the diseases. However, studies related to pomegranate application in fish are scanty.

Pomegranate (Punica granatum) is an edible fruit belonging to the family of Punicaceae, native of Iran and widely cultivated in many countries. All anatomical parts of this fruit (seed, flower, juice, peel, leaf, bark, and root) possess antioxidant, anti-inflammatory, anti-cancer and anti-angiogenesis properties (Seeram et al., 2006). For this reason pomegranate has largely been used as a natural remedy against different pathological conditions (microbial infections, acidosis, dysentery, diarrhea, hemorrhage, and respiratory diseases) (Kim and Choi, 2009).

High levels of antioxidant are contained in pomegranate juice, peel, and seed oil (Schubert et al., 1999; Noda et al., 2002; Singh et al., 2002) and they represent potential candidates as a nutritional supplement for animals feed such as polyunsaturated oil called "punicic acid" (an omega 5 fatty acid) which has strong anti-inflammatory properties, for this it reason it is widely used in medicine and cosmetic (Wang et al., 2004; Boussetta et al., 2009).

In this research pomegranate seed oil (PSO), administered at different rates, was used as feed additive in diets of Rainbow Trout Onchorhynchus mykiss, that is a species farmed in aquaculture both for food and sports in Europe and one of the most valuable fish in world (Satari et al., 2007).

This study designed to determine the effects of PSO, which has not been investigated as a feed additives for rainbow trout on growth performance, hematological and biochemical values and resistance to Yersinia ruckeri infection.

\section{MATERIALS AND METHODS}

\section{Fish and Culture Conditions}

A total of 240 cultured rainbow trout $(6.79 \pm 0.02 \mathrm{~g})$ coming from a commercial aquaculture farm located in Turkey were allocated into $1250 \mathrm{~L}$ aquarium (20 fish/per aquarium) and were allowed to acclimated for 15 days. Each fish was visually inspected externally according to United States Environmental Protection Agency (EPA) guidelines for qualitatively assessing fish health (Klemm et al., 1993).

Four experimental diets $\left(\mathrm{PSO}_{0}, \mathrm{PSO}_{5}, \mathrm{PSO}_{10}\right.$, and $\left.\mathrm{PSO}_{20}\right)$ were obtained by adding the PSO decided by preliminary studies at a rate of $0,0.5,1.0$, and $2.0 \%$ (Table 1 ).

Pomegranate seed oil was provided by "ONEVA," a turkish factory. A basal diet was formulated using commercial feed ingredients (fish meal, soybean meal, wheat meal, corn starch, and fish oil). The ingredients were blended in a mixer and pelleted using meat grinder. Pellets were dried in a heater at $30^{\circ} \mathrm{C}$ for $48 \mathrm{~h}$ and stored at $-18^{\circ} \mathrm{C}$ in plastic bags until use.

Pomegranate seed oil was added to the feed at 5, 10, and $20 \mathrm{~g} / \mathrm{kg}$. The control diet did not have any addition (Table 1).

The daily water change was made up to approximately half of total tank volume. The experiment diets were given for consumption to the fish three times a day as ad libitum at 09:00, 13:00, and 17:00 for 60 days. Water parameters were measured throughout the experiment as temperature was $15.2 \pm 0.1^{\circ} \mathrm{C}, \mathrm{pH}$ was $7.2 \pm 0.2$, and dissolved oxygen was $8.33 \pm 0.2 \mathrm{mg} / \mathrm{L}$.

\section{Determination of Growth Performance}

When the 60 days experiment was over, each fish in all groups (a total of 240) were gained weight and the parameters of growth performance was calculated as following formulas:

Relative Growth Rate(RGR \%) = (final weight - initial weight) / initial weight

Specific Growth Rate $($ SGR $)=100 \times \ln ($ final weight $/$ initial

/ days of experiment

Feed Conservation Rate (FCR) = Feed Intake(g dry weight)/ (final weight - initial weight).

The AOAC the standard method was applied for feed materials and experiment diets in order to determine moisture, ash, crude protein, and lipid (Helrich, 1990). The samples were digested with acid by using the auto Kjeldahl system and crude protein was detected according to Kjeldahl method. Soxtec system was used by the ether extraction method to determine crude lipid, moisture was determined using by oven drying at $105^{\circ} \mathrm{C}$ until constant weight was reached. The samples were placed in a muffle furnace at $550^{\circ} \mathrm{C}$ for $24 \mathrm{~h}$ and then ash content was measured.

\section{Blood Collection and Analyses}

Blood was withdrawn from the caudal vein (three fish per aquarium per dietary group were anesthetised by MS222 as indicate by Topic Popovic et al. (2012), at the concentration of $0.7 \mathrm{~g} / \mathrm{L}$ ) at the end of the feeding experiment using $18 \mathrm{G} \times 1.5$ syringes rinsed with EDTA. Then blood was transferred into two different tubes, one (Miniplast $0.6 \mathrm{~mL}$; LP Italiana Spa, Milan) containing ethylenediaminetetraacetic 
TABLE 1 | Percentage and proximate composition of the experimental diets containing supplement of different PSO rate.

\begin{tabular}{|c|c|c|c|c|}
\hline Ingredients composition (g/100 g) & $\mathrm{PSO}_{0}$ & $\mathrm{PSO}_{5}$ & $\mathrm{PSO}_{10}$ & $\mathrm{PSO}_{20}$ \\
\hline Fish meal $^{1}$ & 40.2 & 40.2 & 40.2 & 40.2 \\
\hline Soybean meal ${ }^{2}$ & 30 & 30 & 30 & 30 \\
\hline Wheat meal ${ }^{2}$ & 7 & 7 & 7 & 7 \\
\hline Corn starch ${ }^{2}$ & 6.8 & 6.8 & 6.8 & 6.8 \\
\hline Fish oil ${ }^{3}$ & 12 & 11.5 & 11 & 10 \\
\hline Pomegranate oil & 0 & 0.5 & 1 & 2 \\
\hline Vitamin-mineral $^{4}$ & 4 & 4 & 4 & 4 \\
\hline Total & 100 & 100 & 100 & 100 \\
\hline \multicolumn{5}{|l|}{ Gross composition (\% DM) } \\
\hline Protein & 43.55 & 43.44 & 43.37 & 43.21 \\
\hline Lipid & 17.21 & 17.29 & 17.37 & 17.40 \\
\hline Ash & 7.66 & 7.71 & 7.56 & 7.64 \\
\hline
\end{tabular}

${ }^{1}$ Anchovy fish meal, Koptur Balıkçılık, Trabzon, Turkey.

${ }^{2}$ Soybean meal, Agromarin Yem San.ve Tic. A.Ş., Izmir, Turkey.

${ }^{3}$ Anchovy fish oil, AgromarinYem San.ve Tic. A.Ş., Izmir, Turkey.

${ }^{4}$ Vitamin mixture: vitamin A, $18000 \mathrm{lU} / \mathrm{kg}$ feed; vitamin $D_{3}, 2500 \mathrm{lU} / \mathrm{kg}$ feed; vitamin E, $250 \mathrm{mg} / \mathrm{kg}$ feed; vitamin $K_{3}, 12 \mathrm{mg} / \mathrm{kg}$ feed; vitamin $B_{1}, 25 \mathrm{mg} / \mathrm{kg}$ feed; vitamin $B_{2}, 50 \mathrm{mg} / \mathrm{kg}$ feed; vitamin $B_{3}, 270 \mathrm{mg} / \mathrm{kg}$ feed; vitamin $B_{6}, 20 \mathrm{mg} / \mathrm{kg}$ feed; vitamin $\mathrm{B}_{12}, 0.06 \mathrm{mg} / \mathrm{kg}$ feed; vitamin C, $200 \mathrm{mg} / \mathrm{kg}$ feed; folic acid, $10 \mathrm{mg} / \mathrm{kg}$ feed; calcium D-pantothenate, $50 \mathrm{mg} / \mathrm{kg}$ feed; biotin, $1 \mathrm{mg} / \mathrm{kg}$ feed; inositol, $120 \mathrm{mg} / \mathrm{kg}$ feed; choline chloride, $2000 \mathrm{mg} / \mathrm{kg}$ feed.

Mineral mixture (mg/kg): Fe, 75.3 mg; Cu, 12.2 mg; Mn, 206 mg; Zn, 85 mg; l, $3 \mathrm{mg}$; Se, $0.350 \mathrm{mg}$; Co, $1 \mathrm{mg}$.

acid (EDTA) (ratio $1.26 \mathrm{mg} / 0.6 \mathrm{~mL}$ ) as anticoagulant agent for the assessment of hematological parameters and the other (Terumo Corporation, Japan) without anticoagulant agent for the assessment of biochemical and immunological parameters.

Blood samples were centrifuged $\left(10 \mathrm{~min}\right.$ at $3000 \mathrm{~g}$ at $\left.4^{\circ} \mathrm{C}\right)$ to obtained sera for biochemical and immunological analysis and stored at $-20^{\circ} \mathrm{C}$ until they were used.

Serum lysozyme activity was assessed using turbidimetric analysis (Nudo and Catap, 2011). $25 \mu \mathrm{L}$ of each serum were mixed with $175 \mu \mathrm{L}$ of Micrococcus luteus (Sigma, ATCC 4698) suspension at $0.75 \mathrm{mg} / \mathrm{mL}$ in phosphate/citrate buffer. The mixture was incubated at $25^{\circ} \mathrm{C}$, and its OD was measured after $30 \mathrm{~min}$ at $530 \mathrm{~nm}$ using a plate reader (Thermo Multiskan Go). Hen egg white lysozyme was used as an external standard. The rate of reduction was converted in absorbance of the samples to lysozyme concentration $(\mu \mathrm{g} / \mathrm{mL})$ using a standard curve.

Total myeloperoxidase (MPO) content was measured according to Quade and Roth (1997) and Sahoo et al. (2005) with minor modifications. $10 \mu \mathrm{l}$ serum was diluted with $90 \mu \mathrm{l}$ of HBSS without $\mathrm{Ca}^{2+}$ or $\mathrm{Mg}^{2+}$ in 96 well plate. $35 \mu \mathrm{L}$ of

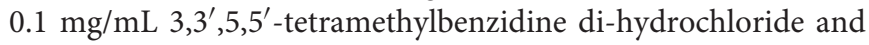
$0.006 \%$ fresh hydrogen peroxide were added. After $2 \mathrm{~min}, 35 \mu \mathrm{L}$ of $4 \mathrm{~mol} / \mathrm{l}$ sulfuric acid was added to stop the reaction and the optical density was read at $450 \mathrm{~nm}$ in a plate reader.

The method of Blaxhall and Daisley (1973) was used to determine red blood cell (RBC) count $\left(\times 10^{6}\right.$ per $\left.\mathrm{mm}^{3}\right)$, hematocrit (Hct; \%), and hemoglobin $(\mathrm{Hb})$ concentration $(\mathrm{g} / \mathrm{L})$. The RBC count was obtained with a Thoma hemocytometer using Dacie's diluting fluid. A capillary Hct tube was used to determine the Hct value. The $\mathrm{Hb}$ concentration was measured by spectrophotometry $(540 \mathrm{~nm})$ via the cyanmethemoglobin method. Mean corpuscular volume (MCV), mean corpuscular $\mathrm{Hb}(\mathrm{MCH})$, and mean corpuscular $\mathrm{Hb}$ concentrations (MCHC) were calculated with the following formulae (Bain et al., 2006):

$$
\begin{aligned}
\operatorname{MCV}\left(\mu \mathrm{m}^{3}\right) & =[(\mathrm{Hct}, \%) \times 10] /\left(\mathrm{RBC}, \times 10^{6} \text { permm }^{3}\right) \mid \\
\operatorname{MCH}(\mathrm{pg}) & =[(\mathrm{Hb}, \mathrm{g} / \mathrm{L}) \times 10] /\left(\mathrm{RBC}, \times 10^{6} \text { permm }^{3}\right) \\
& \operatorname{MCHC}(\%)=[(\mathrm{Hb}, \mathrm{g} / \mathrm{L}) \times 100] /(\mathrm{Hct}, \%) .
\end{aligned}
$$

Sera bio-chemical variables [CHOL (cholesterol), TRIG (triglyceride), GLO (globulin), ALB (albumin), TP (total protein), and GLU (glucose)] were detected with bio analytic test kits (Bioanalytic Diagnostic Industry, Co.) and absorbance value was measured by using spectrophotometer (Optizen POP UV/VIS).

\section{Challenge Experiment With Y. ruckeri}

A pathogenic pathogen Y. ruckeri (E42 Accession No: KX388238) was used. A stock of bacteria stored in tryptic soy broth containing $15 \%$ glycerol was prepared and maintained at $-80^{\circ} \mathrm{C}$. Briefly, 2 days before the challenge an aliquot of the bacteria was grown in tryptic soy broth medium at $22^{\circ} \mathrm{C}$ in a shaker incubator. After 1 day, the bacterial suspension was serially diluted in sterile PBS until the stock bacteria contained $\sim 10^{7}$ colony forming units (cfu) $/ \mathrm{mL}$.

For the challenge, 51 rainbow trout per groups (17 fish/aquarium) were anesthetised with MS222 (as described above), and injected intraperitoneally (i.p.) with $6.8 \times 10^{6} \mathrm{cfu} / \mathrm{mL}$ of $Y$. ruckeri in PBS $(0.1 \mathrm{~mL} / \mathrm{fish})$. The density of the bacteria was determined according to the previously calculated LD50 value for the rainbow trout juveniles. Dead fish were recorded daily and the fish were taken from the aquarium for 20 days. The bacterium was re-isolated from the dead fish.

\section{Procedure of Gas Chromatography-Mass Spectrometry (GC-MSD to Determine the Content of Pomegranate Oil}

Analyses of the cold-press oil were performed using a Shimadzu GCMS QP 2010 ULTRA GC-MS system operating in the EI mode $0.70 \mathrm{~kW}$, equipped with a split/splitless injector $\left(250^{\circ} \mathrm{C}\right)$. The interface temperature was $250^{\circ} \mathrm{C}$. Helium was used as carrier gas $(1.26 \mathrm{~mL} / \mathrm{min})$ in capillary column and the capillary column used was: RTX-5MS (30 m; $0.25 \mathrm{~mm} ; 0.25 \mu \mathrm{m}$ ). The temperature program was the same with that used for the GC analysis; split ratio 1:5. The injected volume was $1 \mu \mathrm{L}$. Acquisition mass range $45-450 \mathrm{~m} / \mathrm{z}$. The identification of the compounds was based on comparison of their retention times (RTs), and/or Wiley libraries, and the literature (Adams, 2007).

\section{Statistical Analysis}

In this study, analytical data were represented as mean (M) \pm standard error of the main (SEM) and they are the averages of three analyses carried out by the same operator. Samples exhibited parallel displacement to the standard curve. The overall intra-assay coefficient of variation was $<9 \%$. 
Kolmogorov-Smirnov test was used to test for normality the data obtained for different blood parameters. The value $P<0.05$ was considered statistically significant.

The influence of PSO on measured blood parameters in trout was evaluated by the application of One-way analysis of variance (ANOVA), Bonferroni's multiple comparison test was used for post hoc comparison.

To analyze the data statistical software prism v. 5.00 (GraphPad Software, Ltd., United States, 2003) was used. Kaplan-Meier analysis was applied to estimate the survival of fish in each $Y$. ruckeri-challenged treatment group, and differences between groups were assessed with the log-rank (Mantel-Cox) test for pair wise comparisons.

\section{RESULTS}

Gas chromatography-mass spectrometry (GC-MS) analysis results showed that the major components of PSO were Squalene (45.09\%), $\Delta$ - Tocopherol (37.01\%), and ethyl linoleate (5.29\%).
Variations (means \pm SEM) of data related to growth performance, hematological, biochemical, and immunological parameters are reported in Table 2.

The application of one-way ANOVA showed a significant effect of PSO on some blood parameters in the experimental Groups with respect to control. In particular, groups $\mathrm{PSO}_{5}$ and $\mathrm{PSO}_{10}$ showed significantly $(P<0.05)$ higher levels of $\mathrm{RBC}, \mathrm{Hb}, \mathrm{MCHC}$, and significantly $(P<0.05)$ lower levels of aspartate aminotransferase (AST), alanine aminotransferase (ALT), and alkaline phosphatase (ALP) respectively than control, while all three experimental Groups $\left(\mathrm{PSO}_{5}, \mathrm{PSO}_{10}\right.$ and $\left.\mathrm{PSO}_{20}\right)$ showed significantly $(P<0.05)$ at lower levels of $\mathrm{CHOL}$ respectively than control. Only in group $\mathrm{PSO}_{10}$ significantly lower values of MCV with respect to control were showed.

No significant differences were found in Hct, MCH, GLU, TP, ALB, GLO, TRIG, LYS, and MPO between treatment groups.

After 60 days of feeding, fish were challenged with Y. ruckeri and cumulative mortality was recorded for 20 days (Figure 1).

Cumulative survival was $45.10 \%$ in fish fed in the control diet. However, in fish fed the $\mathrm{PSO}_{5}, \mathrm{PSO}_{10}$, and $\mathrm{PSO}_{20}$ supplemented

TABLE 2 | Mean values \pm SEM of growth, hematological, biochemical, and immunological parameters recorded in control and experimental groups

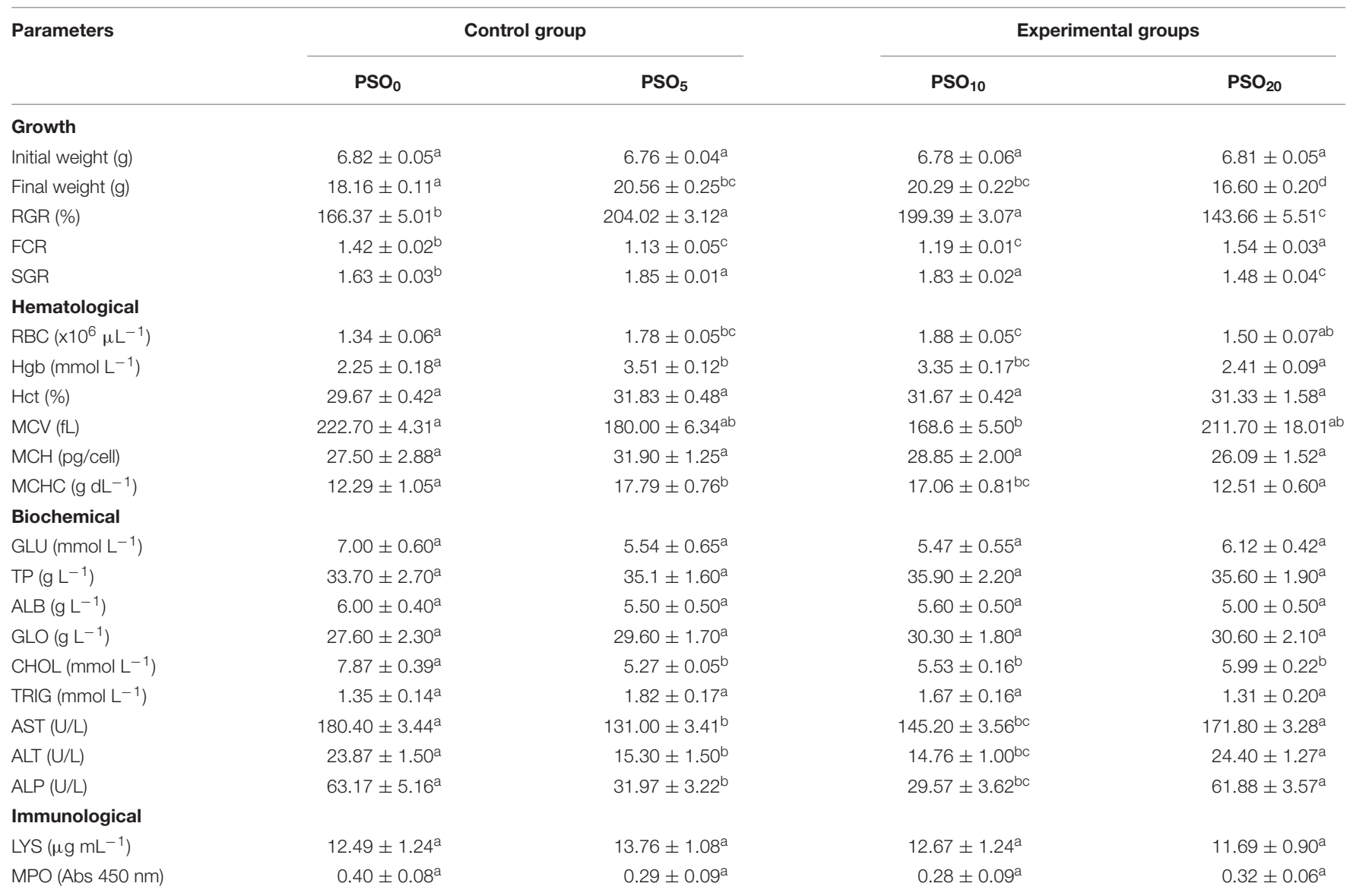

Means with different alphabetical characters in the same row are statistically different (ANOVA, Bonferroni test; $P<0.05$ ).

$R G R$, relative growth rate; $F C R$, feed conversion rate; SGR, specific growth rate; $R B C$, red blood cell; $H$ gb, hemoglobin; Hct, hematocrit: $M C V$, mean cell volume; $M C H$, mean cell hemoglobin; MCHC, mean cell hemoglobin concentration; GLU, glucose; TP, total protein; ALB, albumin; GLO, globulin; CHOL, cholesterol; TRIG, triglyceride; AST, aspartate transaminase; ALT, alanine transaminase ALP, alkaline phosphatase; LYS, lysozyme; MPO, myeloperoxidase. 


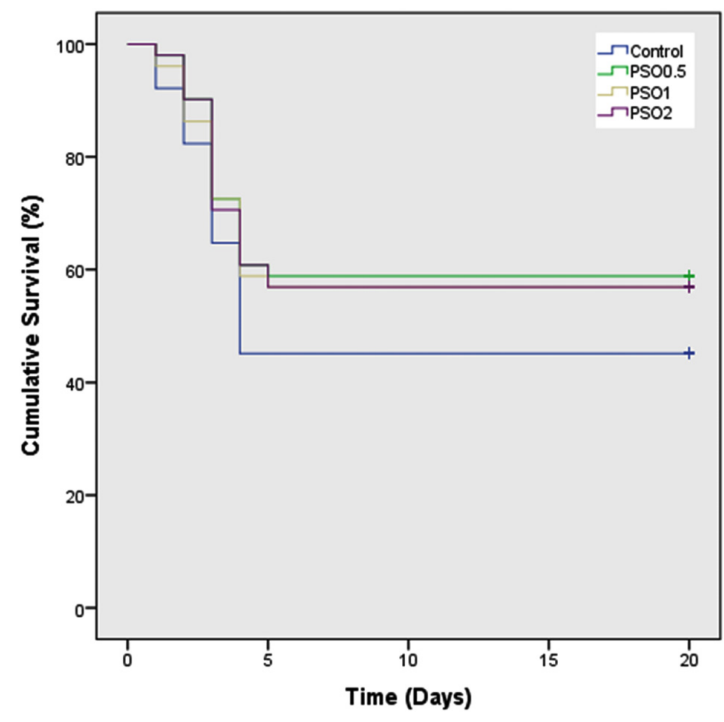

FIGURE 1 | Kaplan-Meier survivorship curves (cumulative survival [\%] over time [days]) for rainbow trout after challenge with Yersinia ruckeri; the fish were fed with pomegranate seeds oil supplemented diets $(0,5,10$, or $20 \mathrm{~g}$ of $\mathrm{PSO} / \mathrm{kg}$ of feed; diets $\mathrm{PSO}_{0}, \mathrm{PSO}_{5}, \mathrm{PSO}_{10}$, and $\mathrm{PSO}_{20}$, respectively) prior to bacterial challenge $209 \mathrm{~mm} \times 232 \mathrm{~mm}(300 \times 300 \mathrm{DPl})$.

diets, survival was 58.82, 56.86, and 56.86\%, respectively. All treated groups challenged with $Y$. ruckeri showed slightly reduced $(P>0.05)$ mortality compared to the $\mathrm{PSO}_{0}$.

\section{DISCUSSION}

Pomegranate seed oil has been established to have many pharmacological properties in terrestrial animal and aquatic species (Gil et al., 2000; Vidal et al., 2003; Badawi and Gomaa, 2016). But no information to date is available about its effects on growth and immunity of rainbow trout. The results of the present study demonstrated that PSO addition up to $10 \mathrm{~g} / \mathrm{kg}$ in the diets barely affected the rainbow trout growth performance. Similar to our results the growth promoting effects has been reported other plant based feed additives (Nya and Austin, 2009; Nootash et al., 2013). In addition to this research (Baba et al., 2017) reported that Nile tilapia (Oreochromis niloticus) showed better growth performance when fed with $10 \mathrm{~g} / \mathrm{kg}$ argan oil supplemented diets. This results suggesting that plant based feed additives has probable effects on modulation of intestine microbiota and digestive process therefore these supplements were improves growth performance of fish (MacLennan et al., 2002). Changes in $\mathrm{RBC}, \mathrm{Hct}, \mathrm{Hb}$ values, and erythrocyte indexes were important to evaluate the health status of organs (Başusta, 2005). In our study, hematocrit levels for rainbow trout fed with PSO supplemented did not show significant differences compared with the control group. Similar results were documented in different fish species fed with Citrus sinensis peel oil (Acar et al., 2015). Studies on fish hemoglobin shows that it is an important tool for health and it can be used for finding out about factors concerning their oxygen-carrying capacity (Wells et al., 2005). Our study showed that also $\mathrm{RBC}, \mathrm{Hb}$, and $\mathrm{MCHC}$ levels increased in fish treated with PSO at 0.5 and $1.00 \%$ levels. Hemoglobin $(\mathrm{Hb})$ is a very important protein with which $\mathrm{RBC}$ is the key for blood oxygen $\left(\mathrm{O}_{2}\right)$ transport in nearly all vertebrates and some invertebrates; this protein optimizes tissue $\mathrm{O}_{2}$ delivery by increasing the total $\mathrm{O}_{2}$ that can be transported in the blood (Rummer and Brauner, 2015). This suggests that PSO improves the performance of the oxygen transport thus promotes a better tissue perfusion.

Serum biochemistry represents a useful index of fish health status to determine physiological changes following different feeding experiment (Y1lmaz and Ergun, 2012). The present study showed that dietary PSO showed no adverse effect on serum total protein, glucose, globulin, and albumin values of fish. However, the results of this study showed significantly decreased in cholesterol values of fish fed with $\mathrm{PSO}_{5}$ and $\mathrm{PSO}_{10}$ diets. The reduces in cholesterol values can be explained with the polyunsaturated fatty acids and other constituents of PSO. Baba et al. (2017) obtained similar results in tilapia (Oreochromus niloticus) fed with argan oil supplemented diets.

In particular, it was observed a significant reduction of AST, ALT, ALP (specific enzymes that are indicators of cellular toxicity) in fish treated at $\mathrm{PSO}_{5}$ and $\mathrm{PSO}_{10}$ groups compared to control; instead at $\mathrm{PSO}_{20}$ these parameters returned control value. These results suggest an evident protective function or did not adversely effect of PSO on fish liver and are in line with those reported in a recent study by Badawi and Gomaa (2016) who studied the effects of diets supplemented by pomegranate peel extract (PPE) at rate of $0.1,0.2,0.3$, and $0.5 \%$ in another species of fish (Nile Tilapia O. niloticus). A marked protective effect of PSO on liver function that decreased AST; ALT and ALP was also shown by Ibrahim (2010) in a previous study on rat. Decrease in enzyme activities can be regarded as an indicator of the protective effect of pomegranate oil on cells, tissues, and organs (Babalola et al., 2009) reported that vegetable oil sources (sunflower and cocoa butter) used in feeds of ductal fish increased liver enzymatic activities, which may be due to damage to liver cell membranes leading to the release of transaminases from the cytoplasm.

With regard to the immunological status, in a previous study of Badawi and Gomaa (2016), it was shown that PPE improved immune status by causing a significant increase in two important indices values of non-specific immunity (IgM and lysozyme) with respect to control; however, in our study the levels of lysozyme and myeloperoxidase did not show any significant difference $(P<0.05)$ in the fish fed with PSO supplemented diet with respect to control. The negligible effects on lysozyme and myeloperoxidase content showed in our results were also found in rainbow trout fed diets enrichment with herbal feed additives (Awad and Austin, 2010; Nya and Austin, 2011; Bulfon et al., 2017). Disagree with our results sweet orange (Citrus sinensis) essential oil (Acar et al., 2015) in tilapia seems to determine an increase of lysozyme activity. Similarly, in Ictalurus punctatus fed with oregano (Origanum heraleoticum) essential oil it was observed an increase in lysozyme activity respect to the control group (Zheng et al., 2009). This discrepancy is mainly due to the different substance administered, experimental conditions, 
fish species and probably at the different absorption capacities of the fish.

At the end of 60 days feeding trial to determine the resistance of rainbow trout to the enteric red mount disease fish were challenge with $Y$. ruckeri. The cumulative survival in rainbow trout fed with $\mathrm{PSO}_{5}, \mathrm{PSO}_{10}$, and $\mathrm{PSO}_{20}$ diets was 52.82, 56.86, and $56.86 \%$, respectively and found significantly different from $\mathrm{PSO}_{0}$ group. It was observed that cinnamon (Cinnamomum verum) and clove oils (Syzygium aromaticum) reduced mortality in Nile tilapia after challenge with S. iniae and Lactococcus garvieae, respectively (Rattanachaikunsopon and Phumkhachorn, 2009, 2010). These results indicate that dietary treatment with various herb oils usually has a positive effect on infected fish, thus increasing survival rates. This aspect is probably due to the interdependent influences of the active components of herb oils and to the hormesis effect. Hormesis is a phenomenon typically associated with the fields of health and toxicology. "Hormesis is a dose-response relationship phenomenon characterized by low-dose stimulation and high-dose inhibition." Depending on the nature of the parameter being affected, the direction of that response changes (Calabrese and Baldwin, 2003). Biological systems exposed to wide range of stimuli show diverse responses depending on the dose; hormesis is considered an adaptive function.

\section{CONCLUSION}

The variation of responses in immunological parameters can be considered as driven variable condition of the animals but also it could be due to hormesis. The blood response to supplementation different levels of PSO could be hormetic, so in the future researches, it should be necessary to improve this research using other doses of PSO and different food times.

\section{REFERENCES}

Acar, Ü., Kesbiç, O. S., Yılmaz, S., Gültepe, N., and Türker, A. (2015). Evaluation of the effects of essential oil extracted from sweet orange peel (Citrus sinensis) on growth rate of tilapia (Oreochromis mossambicus) and possible disease resistance against Streptococcus iniae. Aquaculture 437, 282-286. doi: 10.1016/j. aquaculture.2014.12.015

Adams, R. P. (2007). Identification of Essential Oils Components by Gas Chromatography/Mass Spectroscopy, 4th Edn. Carol Stream, IL: Allured Publishing Corp.

Alishahi, M., Soltani, M., Mesbah, H., and Esmaeili, A. (2011). Effect of oral prescription of (Silybum marianum) extract on immune response of common carp (Cyprinus carpio). Vet. J. 66, 255-263.

Asadi, M. S., Miavaghefei, A. R., Nematollahi, M. A., Banaee, M., and Ahmadi, J. (2012). Effects of watercress (Nasturtium nasturtium) extract on selected immunological parameters of rainbow trout (Oncorhynchus mykiss). Vet. J. 2, 32-39.

Awad, E., and Austin, B. (2010). Use of lupin, Lupinus perennis, mango, Mangifera indica, and stinging nettle, Urtica dioica, as feed additives to prevent Aeromonas hydrophila infection in rainbow trout, Oncorhynchus mykiss (Walbaum). J. Fish Dis. 33, 413-420. doi: 10.1111/j.1365-2761.2009.01133.x

Baba, E., Acar, Ü., Yilmaz, S., Öntaş, C., and Kesbiç, O. S. (2017). Pre-challenge and post-challenge haemato-immunological changes in Oreochromis niloticus (Linnaeus, 1758) fed, argan oil against Lactococcus garvieae. Aquac. Res. 48, 4563-4572. doi: 10.1111/are.13282
Results of our study showed that, PSO up to $10 \mathrm{~g} / \mathrm{kg}$ in rainbow trout diets could determine an increase of growth performance and an improvement of innate immune response. The results indicated the potential of the PSO on Y. ruckeri infection and it should be as the potential use as a substitute for antibacterial to controlling disease in rainbow trout farming because as antibiotics it should be more future studies on the pharmaceutical properties on this seed using the trout as animal model.

\section{ETHICS STATEMENT}

All the experimental procedures were carried out in accordance with the ethical considerations presented by the European legislation concerning the protection of animals used for scientific purposes (European Directive 2010/63). This study was approved by the local ethics committee for animal experiments of Çanakkale Onsekiz Mart University, Çanakkale, Turkey (Approval No. 2016/05-04).

\section{AUTHOR CONTRIBUTIONS}

ÜA, VP, and FF idea for this study. ÜA, OK, and SY designed the experiments. FF, CS, FA analyzed the data. VP, FF, GLP, and ÜA written the article. All authors have made substantial contributions to each step of the experimental procedure and article preparation.

\section{FUNDING}

The study was supported by Research Found Lo Paro Cod. 6A64.

Babalola, T. O. O., Adebayo, M. A., Apata, D. F., and Omotosho, J. S. (2009). Effect of dietary alternative lipid sources oh haematological parameters and serum constituents Heterobranchus longifilis fingerlings. Trop. Anim. Health Prod. 41, 371-377. doi: 10.1007/s11250-008-9199-1

Badawi, M. E., and Gomaa, A. M. (2016). Influence of diets supplemented with pomegranate peel extract on performance in Oreochromus niloticus. Jpn. J. Vet. Res. 64, 87-94.

Bain, B. J., Lewis, S. M., and Bates, I. (2006). "Basic hematological techniques," in Dacie and Lewis Practical Hematology, eds M. Lewis, B. J. Bain, and I. Bates (Philadelphia: Churchill Livingstone Elsevier), 26-54.

Başusta, G. A. (2005). "Fish hematology and hematological techniques," in Research Techniques in Fish Biology, ed. M. Karatas (Ankara: Nobel Publications), 275-300.

Blaxhall, P. C., and Daisley, K. W. (1973). Routine hematological methods for use with fish blood. J. Fish Biol. 5, 771-781. doi: 10.1111/j.1095-8649.1973.tb0 4510.x

Boussetta, T., Raad, H., Lettéron, P., Gougerot-Pocidalo, M. A., Marie, J. C., Driss, F., et al. (2009). Punicic acid a conjugated linolenic acid inhibits TNF $\alpha$-induced neutrophil hyperactivation and protects from experimental colon inflammation in rats. PLoS One 4:S6458. doi: 10.1371/journal.pone. 0006458

Bulfon, C., Galeotti, M., and Volpatti, D. (2017). Medicinal plant extracts modulate respiratory burst and proliferation activity of rainbow trout (Oncorhynchus mykiss) leukocytes. Fish Physiol. Biochem. 44, 109-117. doi: 10.1007/s10695017-0417-5 
Calabrese, E. J., and Baldwin, L. A. (2003). Hormesis: the dose-response revolution. Annu. Rev. Pharmacol. 43, 175-197. doi: 10.1146/annurev.pharmtox.43.100901. 140223

Galindo-Villegas, J., and Hosokawa, H. (2004). "Immunostimulants: towards temporary prevention of diseases in marine fish," in Avances en Nutricion Acuícola, eds L. E. Cruz Suarez, D. Ricque Marie, M. G Nieto Lopez, D. Villarreal, U. Scholz, and M. Gonzalez (Monterrey: Universidad Autónoma de Nuevo León), 279-319.

Gil, M. I., Tomás-Barberán, F. A., Hess-Pierce, B., Holcroft, D. M., and Kader, A. A. (2000). Antioxidant activity of pomegranate juice and its relationship with phenolic composition and processing. J. Agric. Food Chem. 48, 4581-4589. doi: $10.1021 /$ jf000404a

Haghighi, M., and Sharif Rohani, M. (2013). The effects of powdered ginger (Zingiber officinale) on the haematological and immunological parameters of rainbow trout (Oncorhynchus mykiss). JMPHTR 1, 8-12.

Helrich, W. (1990). Official Methods of Analyses, 5th Edn. Washington, DC: Association of Official Analytical Chemists (AOAC).

Ibrahim, M. I. (2010). Efficiency of pomegranate peel extract as antimicrobial, antioxidant and protective agents. J. Agric. Sci. 6, 338-344.

Johnson, C., and Banerji, A. (2007). Influence of extract isolated from the plant Sesuvium portulacastrum growth and metabolism in freshwater teleost. Labeorohita (Rohu). Fish Technol. 44, 229-234.

Kim, Y. H., and Choi, E. M. (2009). Stimulation of osteoblastic differentiation and inhibition of interleukin-6 and nitric oxide in MC3T3-E1 cells by pomegranate ethanol extract. Phytother. Res. 23, 737-739. doi: 10.1002/ptr.2587

Klemm, D. J., Stober, Q. J., and Lazorchak, J. M. (1993). Fish Field and Laboratory Methods for Evaluating the Biological Integrity of Surface Waters, Environmental Monitoring Systems Laboratory-Cincinnati, Office of Modeling, Monitoring Systems, and Quality Assurance, Office of Research and Development. Cincinnati, $\mathrm{OH}$ : US Environmental Protection Agency.

MacLennan, A. H., Wilson, D. H., and Taylor, A. W. (2002). The escalating cost and prevalence of alternative medicine. Prev. Med. 35, 166-173. doi: 10.1006/pmed. 2002.1057.166

Noda, Y., Kaneyuki, T., Mori, A., and Packer, L. (2002). Antioxidant activities of pomegranate fruit extract and its anthocyanidins: delphinidin, cyanidin, and pelargonidin. J. Agric. Food Chem. 50, 166-171. doi: 10.1021/jf0108765

Nootash, S., Sheikhzadeh, N., Baradaran, B., Oushani, A. K., Moghadam, M. R. M., Nofouzi, K., et al. (2013). Green tea (Camellia sinensis) administration induces expression of immune relevant genes and biochemical parameters in rainbow trout (Oncorhynchus mykiss). Fish Shellfish Immunol. 35, 1916-1923. doi: 10. 1016/j.fsi.2013.09.030

Nudo, L. P., and Catap, E. S. (2011). Immunostimulatory effects of Uncaria perrottetii (A. Rich.) Merr.(Rubiaceae) vinebark aqueous extract in Balb/C mice. J. Ethnopharmacol. 133, 613-620. doi: 10.1016/j.jep.2010.10.044

Nya, E. J., and Austin, B. (2009). Use of garlic, Allium sativum, to control Aeromonas hydrophila infection in rainbow trout, Oncorhynchus mykiss (Walbaum). J. Fish Dis. 32, 963-970. doi: 10.1111/j.1365-2761.2009.01100.x

Nya, E. J., and Austin, B. (2011). Development of immunity in rainbow trout (Oncorhynchus mykiss, Walbaum) to Aeromonas hydrophila after the dietary application of garlic. Fish Shellfish Immunol. 30, 845-850. doi: 10.1016/j.fsi. 2011.01 .008

Quade, M. J., and Roth, J. A. (1997). A rapid, direct assay to measure degranulation of bovine neutrophil primary granules. Vet. Immunol. Immunopathol. 58, 239-248. doi: 10.1016/S0165-2427(97)00048-2

Rattanachaikunsopon, P., and Phumkhachorn, P. (2009). Protective effect of clove oil-supplemented fish diets on experimental Lactococus graviae infection in tilapia. Biosci. Biotechnol. Biochem. 73, 2085-2089. doi: 10.1271/bbb.90294
Rattanachaikunsopon, P., and Phumkhachorn, P. (2010). Potential of cinnamon (Cinnamomum verum) oil to control Streptococcus iniae infection in tilapia (Oreochromis niloticus). Fish. Sci. 76, 287-293. doi: 10.1007/s12562-010-0218-6

Rummer, J. L., and Brauner, C. J. (2015). Root effect haemoglobins in fish may greatly enhance general oxygen delivery relative to other Vertebrates. PLoS One 10:S0139477. doi: 10.1371/journal.pone.0139477

Sahoo, P. K., Kumari, J., and Mishra, B. K. (2005). Non-specific immune responses in juveniles of Indian major carp. J. Appl. Ichthyol. 21, 151-155. doi: 10.1111/j. 1439-0426.2004.00606.x

Sasmal, D., Babu, C. S., and Abraham, T. J. (2005). Effect of garlic (Allium sativum) extract on the growth and disease resistance of Carassius auratus (Linnaeus, 1758). Indian J. Fish. 52, 207-214.

Satari, M., Shahsavani, D., and Shafiee, S. H. (2007). Systematic Ichthyology. Rasht: Haqshenas Publications.

Schubert, S. Y., Lansky, E. P., and Neeman, I. (1999). Antioxidant and eicosanoid enzyme inhibition properties of pomegranate seed oil and fermented juice flavonoids. J. Ethnopharmacol. 66, 11-17. doi: 10.1016/S0378-8741(98)00222-0

Seeram, N. P., Schulman, R. N., and Heber, D. (2006). Pomegranates: Ancient Roots to Modern Medicine. Boca Raton, FL: Taylor and Francis Group.

Singh, R. P., Murthy, K. N. C., and Jayaprakasha, G. K. (2002). Studies on antioxidant activity of pomegranate (Punica granatum) peel and seed extracts using in vitro models. J. Agric. Food Chem. 50, 81-86. doi: 10.1021/jf010865b

Tangestani, R., Alizadedughikolaei, E., Ebrahimi, E., and Zare, P. (2011). Effect of garlic (Allium sativum) essential oil on haematological parameters of juvenile beluga (Huso huso). J. Vet. Res. 663, 209-214.

Topic Popovic, N., Strunjak-Perovic, I., Coz-Rakovac, R., Barisic, J., Jadan, M., Persin Berakovic, A., et al. (2012). Tricaine methane-sulfonate (MS-222) application in fish anaesthesia. J. Appl. Ichthyol. 28, 553-564. doi: 10.1111/j. 1439-0426.2012.01950.x

Vidal, A., Fallarero, A., Pena, B. R., Medina, M. E., Gra, B., Rivera, F., et al. (2003). Studies on the toxicity of Punica granatum L. (Punicaceae) whole fruit extracts. J. Ethnopharmacol. 89, 295-300. doi: 10.1016/j.jep.2003.09.001

Wang, R. F., Xie, W. D., Zhang, Z., Xing, D. M., Ding, Y., Wang, W., et al. (2004). Bioactive compounds from the seeds of Punica granatum (pomegranate). J. Nat. Prod. 67, 2096-2098. doi: 10.1021/np0498051

Wells, R. M. G., Baldwins, J., Seymour, R. S., Christian, K., and Brittain, T. (2005). Red blood cell function and haematology in two tropical freshwater fishes from Australia. Comp. Biochem. Phys. A 141, 87-93. doi: 10.1016/j.cbpb.2005.04.005

Yilmaz, S., and Ergun, S. (2012). Effects of garlic and ginger oils on hematological and biochemical parameters of Sea Bass, Dicentrarchus labrax. J. Aquat. Anim. Health 24, 219-224. doi: 10.1080/08997659.2012.711266

Zheng, Z. L., Tan, J. Y. W., Liu, H. Y., Zhou, X. H., Xiang, X., and Wang, K. Y. (2009). Evaluation of oregano essential oil (Origanum heracleoticum L.) on growth, antioxidant effect and resistance against Aeromonas hydrophila in channel catfish (Ictalurus punctatus). Aquaculture 292, 214-218.

Conflict of Interest Statement: The authors declare that the research was conducted in the absence of any commercial or financial relationships that could be construed as a potential conflict of interest.

Copyright (c) 2018 Acar, Parrino, Kesbiç, Lo Paro, Saoca, Abbate, Yılmaz and Fazio. This is an open-access article distributed under the terms of the Creative Commons Attribution License (CC BY). The use, distribution or reproduction in other forums is permitted, provided the original author(s) and the copyright owner are credited and that the original publication in this journal is cited, in accordance with accepted academic practice. No use, distribution or reproduction is permitted which does not comply with these terms. 